\title{
RESEARCH NOTES
}

\section{Redundancy: Trends in Compensation}

\section{Raymond Harbridge and Peter Kiely*}

\section{Introduction}

Redundancy is an unpleasant aspect of working life. Employers, from time to time, find they have too many staff or staff with the wrong skills, and accordingly lay employees off. A recent survey of 400 firms indicated that 9,507 employees had been made redundant in the past year (Russell, McVeigh et al., 1995). Ferguson (1992) identifies various legislators' attempts to tip the balance in favour of employers over the matter of redundancy compensation. Specifically, she identifies:

* S46 (3) of the Employment Contracts Act 1991 which makes it clear that the role of the Courts in determining redundancy compensation is to be limited;

* Social Security Amendment Act 1991, which provided that, as from March 11991 , eligibility for unemployment benefits and family support will be deferred until after redundancy payments, treated as income, have ceased to have effect;

* the Redundancy Payments (Taxation and Benefits) Bill of May 1992, which removed concessional tax rates for redundancy payments and fringe benefit liability for employers and replaced them with a $28 \mathrm{c}$ in the dollar tax on payments to be paid by employees; and

* Encouragement for low redundancy payments by the removal of the 26 week benefit stand-down period for those receiving payments of less than $\$ 9,870$.

Redundancy has become one of the most controversial and judicially active areas of employment jurisdiction. This notwithstanding that Section 46 (3) of the Employment Contracts Act expressly forbids the Employment Court or the Employment Tribunal from fixing a level of redundancy compensation where disputes arise. However, a personal grievance is not a "dispute" in the strict legal sense. The law relating to personal griev-

Associate Professor, Industrial Relations Centre, Victoria University of Wellington and Partner, Hesketh Henry, Auckland, respectively. The research reported herein was in part funded by grants from the Foundation for Research, Science and Technology (VIC 501), Victoria University's Internal Grants Committee and the Faculty of Commerce and Administration. The database project is led by Raymond Harbridge, Kevin Hince and Aaron Crawford. Research assistance is provided by Toby Harbridge, Kristoph Jenkinson, Tony Narby, Bridget Stairmand and Charlie Welch. 
grievances requires that a dismissal must be justified both substantively and procedurally. The latter requirement involves the application of fairness, respect and considerate dealing. As a result, employers at the very least, must consider redundancy compensation if they want to make an employee "fairly" redundant. It is a radical approach to New Zealand's employment law and arguably the most controversial judgment to date.

The Court of Appeal has reviewed the matter of redundancy in Brighouse Limited $v$ Bilderbeck ${ }^{1}$ ruling that when making an employee redundant, the employer must act fairly and reasonably. That in itself is nothing new. In an earlier case, GN Hale \& Son Ltd v Wellington Caretakers IUOW ${ }^{2}$, the Labour Court held that fair dealings of employees who were to be made redundant required a process of consultation, reasonable notice and opportunities for redeployment to be reconsidered.

Brighouse commenced as a personal grievance in the Employment Tribunal. Bilderbeck and three other senior managers were made redundant when the employer sold its business. Each of the four managers received one months notice of termination. However, no redundancy compensation, extended notice, redeployment or re-employment assistance was initially given. Eventually they were paid one weeks salary for each year of service. The four managers alleged they had been unjustifiably dismissed. The Tribunal ruled that the employer's offer of redundancy compensation was inaciequate. The compensation was calculated on a formula of one weeks pay for the first year of service and one week for every year of service after that at a time when four weeks for the first year and two weeks for each year thereafter was reasonably commonplace in collective contracts throughout that industry. The case was appealed to the Employment Court ${ }^{3}$ and subsequently to the Court of Appeal. The Court of Appeal held that redundancy is a dismissal which may give rise to a personal grievance.

Compensation has become a mandatory consideration when determining whether an employer has acted fairly and reasonably in effecting a redundancy. This is a fundamental development and interpretation of the implied term in an employment contract to act fairly and reasonably. Essentially, if the appropriate redundancy compensation has not been paid to a redundant employee, then the dismissal will be held to be unjustified. As the President of the Court of Appeal stated in Brighouse:

If the employee genuinely dismissed the employee on the ground of redundancy . . the employee had no right to continue in employment. In my understanding that decision was not intended to foreclose compensation or to emancipate the employer from the principle of implied trust and respect or considerate dealing. ${ }^{4}$

The potential impact of the Brighouse decision is uncertain and likely to develop over time. There are two fundamental principles which have evolved from the Court of Appeal's decision. These principles represent a development of the law relating to redundancy and personal grievances.

\footnotetext{
19942 ERNZ 243

219903 NZILR 836

319922 ERNZ 161

419942 ERNZ 243, p.253
} 
* Employers and employees as parties to an employment contract must now turn their minds to the issue of redundancy compensation. The time to do this is when the employment contract is negotiated. If the parties do not address the issue of redundancy compensation, then the Court or Tribunal may require an employer to compensate its employees who are made redundant.

* If an employment contract has been negotiated and the parties have expressly turned their minds to redundancy compensation, then a Court may rewrite the provision to ensure that the contract is afforded fairness. The only proviso which the Court has added to this is that it will only ever occur in "exceptional circumstances".

In the words of the President of the Court of Appeal:

\begin{abstract}
If the contract contained an express provision and formula for redundancy compensation or (less likely) an express provision that there shall be no such compensation, no doubt it will govern, save possibly in very exceptional circumstances. Where no express provision applies the ordinary personal grievance will be available and there will be jurisdiction to award compensation .... which the worker might reasonably have been expected to obtain. $^{5}$
\end{abstract}

Some critics have argued that the Court of Appeal has ignored a fundamental principle of the law of contract, namely that the express terms of a contract must always prevail. According to the general law of contract, a term will only ever te implied into a contract if it is required to give that contract business efficacy. Arguably, business efficacy in a contract of employment does not require redundancy compensation to be payable.

The Brighouse decision has enabled the Employment Court to rewrite an employment contract's redundancy provision sometime after it has been negotiated. The Court of Appeal rationalised this "judicial license" on the grounds of implied trust, respect and considerate dealing which have traditionally underpinned the master/servant model of the employment relationship. This approach is one of the most judicially active interpretations to date and the question facing parties to an employment contract is how best can they anticipate the level of compensation that the "worker might reasonably have been expected to obtain". One way to anticipate this question would be to ascertain an industry profile of redundancy compensation and to use that information to assist in determining the appropriate level of compensation to be included in each employment contract.

\title{
Results
}

Including redundancy notice and compensation provisions in employment contracts is a comparatively new development in collective bargaining in New Zealand. Under the previous system of labour regulation, the Labour Relations Act 1987, we established that there were just 227 redundancy agreements (all firm level agreements) registered with the Arbitration Commission (Harbridge, 1992). In the wake of the Brighouse decision, employment advisers have been recommending to clients that redundancy provisions should

\footnotetext{
5 ibid p.255
} 
be included in employment contract settlements. These advisers have had considerable success and redundancy provisions are now contained in contracts covering 77 percent of employees in our database ${ }^{6}$. The data in Table 1 reflects the prevalence of redundancy provisions - with an indication of the type of provision, by selected industries. The education, construction, hotels and cafes, and community services sectors are those where redundancy provisions are most likely to be absent from collective employment contracts. Generally, where redundancy has been considered, the trend is for both notice and compensation to be set out in detail.

ABLE 1: Prevalence of redundancy clauses in collective employment contract

\begin{tabular}{|l|c|c|c|c|c|c|c|c||}
\hline \hline & $\begin{array}{c}\text { No } \\
\text { clause }\end{array}$ & $\begin{array}{c}\text { Pay } \\
\text { only }\end{array}$ & $\begin{array}{c}\text { Pay } \\
\text { and } \\
\text { notice } \\
\%\end{array}$ & $\begin{array}{c}\text { Notice } \\
\text { only }\end{array}$ & $\begin{array}{c}\text { No } \\
\text { details }\end{array}$ & $\begin{array}{c}\text { Stand } \\
\text { alone } \\
\text { contract } \\
\%\end{array}$ & Contracts & $\begin{array}{c}\text { Cover } \\
(000 \text { s) }\end{array}$ \\
\hline All contracts & 23 & 11 & 38 & 15 & 8 & 5 & 2,719 & 371.8 \\
Food mfg & 8 & 8 & 26 & 28 & 6 & 24 & 196 & 21.3 \\
Textile mfg & 18 & 2 & 24 & 53 & 1 & 2 & 109 & 5.7 \\
Wood/paper & 27 & 2 & 38 & 24 & 1 & 8 & 112 & 5.9 \\
mfg & & & & & & & & \\
Printing & 6 & 24 & 59 & 5 & 1 & 5 & 100 & 5.2 \\
Chemical mfg & 4 & 0 & 40 & 44 & 10 & 2 & 155 & 8.3 \\
Metals mfg & 4 & 0 & 47 & 42 & 0 & 7 & 67 & 5.6 \\
Machinery mfg & 8 & 2 & 39 & 42 & 1 & 8 & 224 & 17.5 \\
Utilities & 5 & 4 & 66 & 16 & 9 & 0 & 82 & 5.9 \\
Construction & 46 & 1 & 27 & 7 & 1 & 18 & 70 & 7.7 \\
Wholesaling & 5 & 3 & 63 & 28 & 1 & 0 & 48 & 2.4 \\
Food retailing & 13 & 0 & 46 & 41 & 0 & 0 & 37 & 11.7 \\
Other retailing & 16 & 3 & 39 & 33 & 4 & 5 & 71 & 13.2 \\
Hotels, cafes & 36 & 0 & 28 & 34 & 2 & 0 & 128 & 16.7 \\
Transport & 8 & 11 & 38 & 8 & 2 & 33 & 206 & 17.1 \\
Storage & 6 & 0 & 16 & 59 & 0 & 19 & 10 & 0.3 \\
Communication & 0 & 50 & 50 & 0 & 0 & 0 & 5 & 14.0 \\
Finance & 1 & 2 & 97 & 0 & 0 & 0 & 22 & 20.8 \\
Insurance & 0 & 0 & 82 & 5 & 0 & 13 & 32 & 4.9 \\
Govt adm & 6 & 24 & 56 & 8 & 3 & 3 & 225 & 42.3 \\
Local gvt & 14 & 3 & 49 & 20 & 8 & 6 & 251 & 19.4 \\
Education & 57 & 0 & 3 & 4 & 36 & 0 & 122 & 61.1 \\
Health & 4 & 38 & 42 & 11 & 5 & 0 & 309 & 34.3 \\
Community & 34 & 32 & 15 & 12 & 7 & 0 & 75 & 9.5 \\
svce & & & & & & & & \\
\hline & & & & & & & & \\
\hline
\end{tabular}

Full details about the employment contracts database from which these results are drawn are set out in Harbridge and Honeybone (1995). The sample includes some 2,700 live collective employment contracts covering some 371,000 employees and 11,200 employers. 
There are a number of issues generally taken into account in redundancy provisions:

- period of notice:

- $\quad$ payment (if any) for service for the first year or part thereof;

- $\quad$ payment (if any) for subsequent years of service;

- $\quad$ whether payments have any ceiling imposed;

- $\quad$ whether unused sick leave can be "cashed-up";

- whether any additional payments for "dependents" will be made; and

- $\quad$ whether any existing employee benefits will be continued, and if so, for how long.

Our analysis reviews these issues for contracts where a redundancy provision exists and we have been able to ascertain the exact redundancy provision applying. Table 2 sets out the period of notice of termination of employment should a redundancy situation arise.

Three interesting points emerge. First, four weeks notice of termination of employment through a redundancy situation is commonly provided for. Second, some contracts are silent on the matter of notice, notably contracts in the community services, communications and printing sectors. Third, there are a small number of contracts that provide for no notice of redundancy - in the textile manufacturing industry these same contracts also specifically state that in the event of a redundancy there will be no compensation payments.

A schedule of payments to compensate for redundancy is provided for in contracts covering 49 percent of employees in the sample. The formula for calculating the redundancy payment is almost invariably based on the length of service with the employer. Compensation is paid for the first year of service (or part thereof) and then further compensation for subsequent completed years of service. We present the data on compensation in two tables - Table 3 deals with payments for the first year of service; Table 4 deals with payments for subsequent years.

Again three comments can be made about compensation for the first year of service with the employer. First, a small number of employees are covered by contracts which explicitly refer to redundancy but state that no compensation shall be paid - these employees are concentrated in the textiles, chemical manufacturing and construction industries. Second, nearly a quarter of employees in the sample are on contracts which refer to redundancy (generally specifying the period of notice) but remain silent on the matter of compensation. Third, over half the sample of employees (55 percent) are on contracts which provide for a compensatory payment of six or more weeks pay for the first year of service, with 16 percent being eligible for more than eight weeks compensation for that first year of service.

Payments for subsequent years of service after the first year show less variation. Two weeks pay for each year of service after the first 12 months is available to slightly more than 50 percent of the sample - with 24 percent of employees being on contracts which are silent as to the quantum of payments. 
TABLE 2: Notice (in weeks) of redundancy expressed as the percentage of employees eligible for each period of notice

\begin{tabular}{||l|c|c|c|c|c|c|c|c|c||}
\hline & $\begin{array}{l}0 \\
\text { wks } \\
\%\end{array}$ & $\begin{array}{c}0-4 \\
\text { wks } \\
\%\end{array}$ & $\begin{array}{c}4 \\
\text { wks } \\
\%\end{array}$ & $\begin{array}{c}5-8 \\
\text { wks } \\
\%\end{array}$ & $\begin{array}{c}\text { GT8 } \\
\text { wks } \\
\%\end{array}$ & Other & Silent & Contracts & $\begin{array}{c}\text { Cover } \\
(000 s)\end{array}$ \\
\hline All contracts & 2 & 9 & 62 & 14 & 3 & 1 & 9 & 1886 & 237.8 \\
Food mfg & 0 & 3 & 72 & 13 & 0 & 0 & 12 & 126 & 13.2 \\
Textile mfg & 3 & 14 & 64 & 19 & 0 & 0 & 0 & 85 & 4.5 \\
Wood/paper mfg & 0 & 6 & 90 & 3 & 0 & 0 & 1 & 58 & 3.7 \\
Printing & 1 & 6 & 59 & 5 & 0 & 2 & 27 & 84 & 4.6 \\
Chemical mfg & 0 & 4 & 88 & 7 & 0 & 0 & 1 & 119 & 7.0 \\
Metals mfg & 0 & 2 & 77 & 2 & 19 & 0 & 0 & 52 & 4.9 \\
Machinery mfg & 0 & 2 & 91 & 5 & 0 & 0 & 2 & 176 & 14.5 \\
Utilities & 0 & 18 & 64 & 13 & 1 & 0 & 4 & 61 & 5.1 \\
Construction & 0 & 11 & 85 & 2 & 0 & 0 & 2 & 38 & 2.7 \\
Wholesaling & 0 & 1 & 94 & 2 & 0 & 0 & 3 & 36 & 2.2 \\
Food retailing & 0 & 43 & 55 & 0 & 0 & 2 & 0 & 24 & 10.2 \\
Other retailing & 0 & 10 & 70 & 0 & 0 & 16 & 4 & 46 & 9.9 \\
Hotels, cafes & 0 & 71 & 29 & 0 & 0 & 0 & 0 & 71 & 10.5 \\
Transport & 0 & 29 & 40 & 12 & 6 & 0 & 13 & 138 & 9.8 \\
Storage & 0 & 0 & 80 & 20 & 0 & 0 & 0 & 6 & 0.2 \\
Communication & 0 & 0 & 50 & 0 & 0 & 0 & 50 & 5 & 14.0 \\
Finance & 0 & 0 & 2 & 96 & 0 & 0 & 2 & 20 & 20.5 \\
Insurance & 0 & 0 & 35 & 38 & 27 & 0 & 0 & 32 & 4.9 \\
Govt adm & 9 & 3 & 76 & 4 & 5 & 0 & 3 & 55 & 37.6 \\
Local gvt & 0 & 12 & 66 & 13 & 3 & 1 & 5 & 184 & 14.1 \\
Education & 0 & 2 & 34 & 43 & 7 & 0 & 14 & 63 & 4.9 \\
Health & 0 & 0 & 81 & 2 & 1 & 0 & 16 & 227 & 31.1 \\
Community svce & 0 & 0 & 43 & 0 & 1 & 0 & 56 & 43 & 5.5 \\
& & & & & & & & & \\
\hline
\end{tabular}


TABLE 3: Compensation (in weeks) for the first year of service expressed as the percentage of eligible employees

\begin{tabular}{|c|c|c|c|c|c|c|c|c|c|c|c|c|c|c|}
\hline & $\begin{array}{l}0 \\
\text { wks } \\
\%\end{array}$ & $\begin{array}{l}1 \\
\text { wks } \\
\%\end{array}$ & $\begin{array}{l}2 \\
\text { wks } \\
\%\end{array}$ & $\begin{array}{l}3 \\
\text { wks } \\
\%\end{array}$ & $\begin{array}{l}4 \\
\text { wks } \\
\%\end{array}$ & $\begin{array}{l}5 \\
\text { wks } \\
\%\end{array}$ & $\begin{array}{l}6 \\
\text { wks } \\
\%\end{array}$ & $\begin{array}{l}7 \\
\text { wks } \\
\%\end{array}$ & $\begin{array}{l}8 \\
\text { wks } \\
\%\end{array}$ & $\begin{array}{l}>8 \\
\text { wks } \\
\%\end{array}$ & $\begin{array}{c}\text { Silent } \\
\qquad\end{array}$ & $\begin{array}{l}\text { Other } \\
\%\end{array}$ & $\begin{array}{l}\text { Con- } \\
\text { tracts }\end{array}$ & $\begin{array}{l}\text { Cover } \\
(000 \text { s) }\end{array}$ \\
\hline All contracts & 2 & 0 & 1 & 1 & 8 & 2 & 24 & 9 & 6 & 16 & 24 & 7 & 1885 & 237.7 \\
\hline Food $\mathrm{mfg}$ & 1 & 1 & 0 & 6 & 18 & 1 & 2 & 0 & 5 & 20 & 45 & 1 & 126 & 13.2 \\
\hline Textile mfg & 17 & 0 & 2 & 0 & 6 & 3 & 3 & 0 & 0 & 2 & 67 & 0 & 85 & 4.5 \\
\hline $\begin{array}{l}\text { Wood/paper- } \\
\mathrm{mfg}\end{array}$ & 1 & 1 & 3 & 2 & 2 & 4 & 30 & 0 & 7 & 8 & 38 & 4 & 58 & 3.7 \\
\hline Printing & 1 & 1 & 2 & 0 & 41 & 1 & 9 & 0 & 30 & 8 & 6 & 1 & 84 & 4.6 \\
\hline $\begin{array}{l}\text { Chemical } \\
\mathrm{mfg}\end{array}$ & 8 & 0 & 0 & 0 & 2 & 0 & 6 & 17 & 3 & 10 & 53 & 1 & 119 & 7.0 \\
\hline Metals mfg & 2 & 0 & 0 & 0 & 9 & 1 & 37 & 0 & 3 & 0 & 48 & 0 & 52 & 4.9 \\
\hline $\begin{array}{l}\text { Machinery } \\
\mathrm{mfg}\end{array}$ & 2 & 3 & 1 & 0 & 10 & 2 & 11 & 0 & 12 & 0 & 51 & 8 & 176 & 14.5 \\
\hline Utilities & 0 & 0 & 0 & 1 & 9 & 0 & 26 & 1 & 16 & 27 & 19 & 1 & 61 & 5.1 \\
\hline Construction & 7 & 5 & 3 & 1 & 43 & 0 & 9 & 0 & 0 & 0 & 21 & 11 & 38 & 2.7 \\
\hline Wholesaling & 0 & 2 & 1 & 0 & 2 & 0 & 47 & 0 & 8 & 8 & 32 & 0 & 36 & 2.2 \\
\hline $\begin{array}{l}\text { Food } \\
\text { retailing }\end{array}$ & 2 & 0 & 2 & 0 & 0 & 0 & 20 & 0 & 29 & 0 & 47 & 0 & 24 & 10.2 \\
\hline $\begin{array}{l}\text { Other } \\
\text { retailing }\end{array}$ & 1 & 1 & 0 & 0 & 2 & 7 & 27 & 0 & 0 & 0 & 43 & 19 & 46 & 9.9 \\
\hline Hotels, cafes & 4 & 0 & 0 & 1 & 13 & 0 & 0 & 0 & 0 & 0 & 55 & 27 & 71 & 10.5 \\
\hline Transport & 1 & 1 & 6 & 16 & 13 & 0 & 23 & 0 & 22 & 5 & 13 & 0 & 138 & 9.8 \\
\hline Storage & 0 & 0 & 0 & 0 & 0 & 0 & 1 & 0 & 0 & 20 & 79 & 0 & 6 & 0.2 \\
\hline $\begin{array}{l}\text { Communica- } \\
\text { tion }\end{array}$ & 0 & 0 & 0 & 0 & 0 & 0 & 50 & 0 & 0 & 50 & 0 & 0 & 5 & 14.0 \\
\hline Finance & 0 & 0 & 0 & 0 & 2 & 0 & 0 & 96 & 2 & 0 & 0 & 0 & 20 & 20.5 \\
\hline Insurance & 0 & 0 & 0 & 2 & 1 & 0 & 4 & 23 & 39 & 0 & 5 & 26 & 32 & 4.9 \\
\hline Govt adm & 0 & 0 & 0 & 0 & 4 & 5 & 18 & 0 & 7 & 60 & 4 & 2 & 55 & 37.6 \\
\hline Local govt & 0 & 0 & 0 & 3 & 6 & 0 & 35 & 0 & 18 & 9 & 28 & 1 & 184 & 14.1 \\
\hline Education & 0 & 0 & 0 & 0 & 4 & 10 & 10 & 0 & 0 & 8 & 61 & 7 & 62 & 4.1 \\
\hline Health & 0 & 0 & 0 & 0 & 10 & 0 & 75 & 0 & 0 & 1 & 12 & 2 & 227 & 31.1 \\
\hline $\begin{array}{l}\text { Community } \\
\text { svce }\end{array}$ & 0 & 0 & 0 & 2 & 0 & 0 & 4 & 0 & 0 & 74 & 20 & 0 & 43 & 5.5 \\
\hline
\end{tabular}


TABLE 4: Compensation (in weeks) for subsequent years of service expressed as the percentage of eligible employees

\begin{tabular}{||l|c|c|c|c|c|c|c|c|c|c||}
\hline \hline & $\begin{array}{c}0 \\
\text { wks } \\
\%\end{array}$ & $\begin{array}{c}1 \\
\text { wks } \\
\%\end{array}$ & $\begin{array}{c}2 \\
\text { wks } \\
\%\end{array}$ & $\begin{array}{c}3 \\
\text { wks } \\
\%\end{array}$ & $\begin{array}{c}4 \\
\text { wks } \\
\%\end{array}$ & $\begin{array}{c}\text { GT } \\
4\end{array}$ & $\begin{array}{c}\text { Silent } \\
\%\end{array}$ & Other & Contract & $\begin{array}{c}\text { Cover } \\
(000 s)\end{array}$ \\
\hline All contracts & 4 & 2 & 51 & 4 & 8 & 0 & 24 & 7 & 1885 & 237.7 \\
Food mfg & 1 & 9 & 35 & 2 & 0 & 6 & 46 & 1 & 126 & 13.2 \\
Textile mfg & 17 & 3 & 13 & 0 & 0 & 0 & 67 & 0 & 85 & 4.5 \\
Wood/paper mfg & 1 & 2 & 53 & 2 & 0 & 0 & 38 & 4 & 58 & 3.7 \\
Printing & 0 & 4 & 74 & 12 & 3 & 0 & 6 & 1 & 84 & 4.6 \\
Chemical mfg & 8 & 0 & 23 & 14 & 0 & 0 & 53 & 2 & 119 & 7.0 \\
Metals mfg & 0 & 3 & 49 & 0 & 0 & 0 & 48 & 0 & 52 & 4.9 \\
Machinery mfg & 2 & 5 & 34 & 0 & 0 & 0 & 51 & 8 & 176 & 14.5 \\
Utilities & 0 & 1 & 67 & 9 & 2 & 0 & 19 & 2 & 61 & 5.1 \\
Construction & 7 & 6 & 55 & 0 & 0 & 0 & 21 & 11 & 38 & 2.7 \\
Wholesaling & 0 & 2 & 65 & 1 & 0 & 0 & 32 & 0 & 36 & 2.2 \\
Food retailing & 2 & 2 & 48 & 0 & 0 & 0 & 47 & 1 & 24 & 10.2 \\
Other retailing & 1 & 1 & 36 & 0 & 0 & 0 & 43 & 19 & 46 & 9.9 \\
Hotels, cafes & 6 & 0 & 12 & 0 & 0 & 0 & 55 & 27 & 71 & 10.5 \\
Transport & 1 & 1 & 67 & 18 & 0 & 0 & 13 & 0 & 138 & 9.8 \\
Storage & 0 & 1 & 20 & 0 & 0 & 0 & 79 & 0 & 6 & 0.2 \\
Communication & 0 & 0 & 100 & 0 & 0 & 0 & 0 & 0 & 5 & 14.0 \\
Finance & 0 & 0 & 4 & 12 & 84 & 0 & 0 & 0 & 20 & 20.5 \\
Insurance & 0 & 0 & 66 & 2 & 0 & 0 & 5 & 27 & 32 & 4.9 \\
Govt adm & 2 & 0 & 70 & 4 & 0 & 0 & 9 & 15 & 55 & 30.3 \\
Local govt & 0 & 1 & 64 & 7 & 0 & 0 & 27 & 1 & 184 & 14.1 \\
Education & 0 & 0 & 32 & 0 & 0 & 0 & 61 & 7 & 62 & 4.1 \\
Health & 1 & 0 & 85 & 0 & 0 & 0 & 12 & 2 & 227 & 31.1 \\
Community svce & 56 & 0 & 4 & 20 & 0 & 0 & 20 & 0 & 43 & 5.5 \\
\hline
\end{tabular}

Often redundancy provisions provide for a ceiling on compensatory payments that redundant employees may receive. These ceilings are set out in Table 5. Slightly more than 20 percent of employees are on contracts which do not specify a limit to compensation and a further 25 percent are on contracts which are silent on the "ceiling" issue (as they are on compensation itself) - leading us to conclude that just under half of the sample have no express and explicitly stated limit placed on compensation. Where compensation is limited there are a variety of methods of expressing that limit. In Government administration and defence, employees often have their maximum redundancy payout capped by a dollar amount. Where limits are expressed in terms of the number of weeks pay that can be received, that limit is commonly up to a maximum of between 40 and 52 weeks pay - the main exception to this is in the food retail sector which has often limited redundancy payments of between one and 13 weeks. 
TABLE 5: Maximum compensation (in weeks) payable expressed as the percentage of eligible employees

\begin{tabular}{|c|c|c|c|c|c|c|c|c|c|c|c|c|}
\hline & $\begin{array}{c}S \\
\text { limit } \\
\%\end{array}$ & $\begin{array}{c}0 \\
\text { wks } \\
\%\end{array}$ & $\begin{array}{c}1-13 \\
\text { wks } \\
\%\end{array}$ & $\begin{array}{c}14-26 \\
\text { wks } \\
\% \\
\end{array}$ & $\begin{array}{c}27-39 \\
\text { wks } \\
\% \\
\end{array}$ & $\begin{array}{c}40-52 \\
\text { wks } \\
\%\end{array}$ & $\begin{array}{c}>52 \\
\text { weeks } \\
\%\end{array}$ & $\begin{array}{l}\text { Not } \\
\text { stated } \\
\%\end{array}$ & $\begin{array}{l}\text { Other } \\
\%\end{array}$ & $\begin{array}{l}\text { Silent } \\
\%\end{array}$ & Contracts & $\begin{array}{l}\text { Cover } \\
(000 s)\end{array}$ \\
\hline All contracts & 3 & 2 & 2 & 5 & 2 & 23 & 15 & 21 & 2 & 25 & 1883 & 237.5 \\
\hline Food mfg & 0 & 1 & 2 & 6 & 0 & 19 & 3 & 23 & 1 & 45 & 126 & 13.2 \\
\hline Textile mfg & 0 & 17 & 0 & 2 & 2 & 0 & 0 & 12 & 0 & 67 & 85 & 4.5 \\
\hline $\begin{array}{l}\text { Wood/paper } \\
\mathrm{mfg}\end{array}$ & 0 & 1 & 1 & 1 & 1 & 37 & 14 & 2 & 4 & 39 & 58 & 3.7 \\
\hline Printing & 0 & 1 & 3 & 3 & 37 & 8 & 0 & 42 & 0 & 6 & 81 & 4.6 \\
\hline $\begin{array}{l}\text { Chemical } \\
\mathrm{mfg}\end{array}$ & 0 & 8 & 1 & 2 & 0 & 5 & 1 & 30 & 0 & 53 & 118 & 7.0 \\
\hline Metals mfg & 0 & 2 & 1 & 0 & 3 & 19 & 5 & 23 & 0 & 47 & 52 & 4.9 \\
\hline $\begin{array}{l}\text { Machinery } \\
\mathrm{mfg}\end{array}$ & 0 & 2 & 2 & 3 & 1 & 10 & 8 & 23 & 0 & 51 & 176 & 14.5 \\
\hline Utilities & 0 & 0 & 1 & 4 & 0 & 18 & 5 & 52 & 1 & 19 & 61 & 5.1 \\
\hline Construction & 0 & 6 & 6 & 0 & 0 & 50 & 3 & 2 & 12 & 21 & 38 & 2.7 \\
\hline Wholesaling & 0 & 0 & 2 & 1 & 0 & 1 & 3 & 61 & 0 & 32 & 36 & 2.2 \\
\hline $\begin{array}{l}\text { Food } \\
\text { retailing }\end{array}$ & 0 & 2 & 29 & 0 & 0 & 0 & 0 & 22 & 0 & 47 & 24 & 10.2 \\
\hline $\begin{array}{l}\text { Other } \\
\text { retailing }\end{array}$ & 1 & 1 & 18 & 0 & 0 & 26 & 1 & 10 & 0 & 43 & 46 & 9.9 \\
\hline Hotels, cafes & 0 & 4 & 2 & 37 & 0 & 1 & 0 & 0 & 0 & 56 & 71 & 10.5 \\
\hline Transport & 0 & 1 & 0 & 3 & 3 & 20 & 41 & 16 & 0 & 16 & 138 & 9.8 \\
\hline Storage & 0 & 0 & 0 & 0 & 0 & 0 & 1 & 20 & 0 & 79 & 6 & 0.2 \\
\hline $\begin{array}{l}\text { Communica- } \\
\text { tion }\end{array}$ & 0 & 0 & 0 & 0 & 0 & 50 & 50 & 0 & 0 & 0 & 5 & 14.0 \\
\hline Finance & 0 & 0 & 0 & 0 & 2 & 0 & 96 & 2 & 0 & 0 & 20 & 20.5 \\
\hline Insurance & 0 & 0 & 0 & 0 & 3 & 10 & 1 & 81 & 0 & 5 & 31 & 4.8 \\
\hline Govt adm & 12 & 0 & 0 & 2 & 2 & 18 & 1 & 49 & 7 & 9 & 175 & 37.6 \\
\hline Local gvt & 6 & 0 & 0 & 3 & 3 & 19 & 4 & 37 & 0 & 28 & 184 & 14.1 \\
\hline Education & 0 & 0 & 0 & 0 & 11 & 9 & 11 & 6 & 0 & 63 & 62 & 4.1 \\
\hline Health & 0 & 0 & 0 & 6 & 0 & 70 & 0 & 10 & 0 & 14 & 227 & 30.8 \\
\hline $\begin{array}{l}\text { Community } \\
\text { svce }\end{array}$ & 0 & 0 & 0 & 58 & 0 & 0 & 18 & 4 & 0 & 20 & 43 & 5.5 \\
\hline
\end{tabular}


There are other issues to be considered in determining redundancy payments - should certain benefits that go with the job (e.g. buying privileges, discounted or subsidised benefits such as housing, mortgages and insurance arrangements) be continued and if so for how long. Ten percent of employees are on contracts that address benefits and provide for continuation of these types of benefits, and 25 percent are on contracts that are silent on that issue.

A further issue (predominantly one affecting public employees) is whether the compensation formula will take into account the dependents of the redundant employees. Fourteen percent of employees are on contracts that provide additional compensation for specified dependents.

Possibly the most controversial area is whether unused sick leave can be "cashed up" and taken as part of the redundancy compensation formula. Just eight percent of employees are on contracts that provide for the "cashing up" of unused sick leave - that being a private rather than public sector phenomena. Over two thirds of employees are now on contracts that do not allow for the "cashing up" of unused sick leave - a further reflection of the trend to make paid sick leave applicable only when sickness occurs.

Redundancy is a matter that has often been the subject of grandparenting - where new employees are entitled to less (or none) of the benefits that longer serving staff receive. Fourteen percent of employees in the sample (predominantly in the Government administration and defence and communication sectors) are on contracts where such grandparenting arrangements exist.

\section{Summary}

The findings of this research update can be summarised as follows:

* Employment contracts covering 77 percent of employees in our sample now establish what will happen in the event of a redundancy taking place;

* Commonly four weeks notice of an impending redundancy is given to the employee;

* Contracts covering 49 percent of employees now spell out the levels of compensation that will be paid, with payments being based almost always on length of service;

* $\quad$ For the first year of service, six or more weeks pay as compensation is commonly made;

* For subsequent years of service an additional two weeks pay per year of service is commonly made; and 
* Nearly half of the employees are on contracts with no cap on the level of payments. Where a cap is specified it is often limited at under 52 weeks pay.

While economic uncertainty continues, redundancy will remain a fact of employment and a part of the employment contracts process.

\section{References}

Ferguson, Judith (1992), Personal Grievances Arising from Redundancy: Life After Hale and the Employment Contracts Act 1991, New Zealand Journal of Industrial Relations, 17(3): $371-385$.

Harbridge, Raymond (1992), Recent Redundancy Agreements: A Content Analysis, New Zealand Journal of Industrial Relations, 17(1): 95-100.

Harbridge, Raymond and Honeybone, Anthony (1995), The Employment Contracts Act and Collective Bargaining Patterns: A Review of the 1994/95 Year. In Harbridge, Raymond and Kiely, Peter, (eds) Employment Contracts: Bargaining Trunds and Employment Law Update 1994/95. Wellington, Industrial Relations Centre, Victoria University of Wellington.

Russell, McVeigh, McKenzie, Bartlett and Co (1995), Redundancy in New Zealand, Monograph. Auckland, Russell, McVeigh, McKenzie, Bartlett and Co. 